\title{
Correction to: The disposable bandage soft contact lenses therapy and anterior segment optical coherence tomography for management of ocular graft-versus-host disease
}

\author{
Yi-Chen Sun ${ }^{1,2,3}$, Yoshihiro Inamoto ${ }^{4,5}$, Ruikang K. Wang ${ }^{6}$, Stephanie J. Lee ${ }^{4}$, Kai-Feng Hung ${ }^{7,8^{*}}$ and
} Tueng T. Shen ${ }^{3 *}$

\section{Correction to: BMC Ophthalmol 21, 271 (2021)}

https://doi.org/10.1186/s12886-021-02031-0

Following the publication of the original article [1], we were notified that an affiliation was missed for Yi-Chen Sun: College of Medicine, Tzu-Chi University, Hualien, Taiwan.

The original article has been corrected.

\begin{abstract}
Author details
${ }^{1}$ College of Medicine, Tzu-Chi University, Hualien, Taiwan. ${ }^{2}$ Department of Ophthalmology, Taipei Tzu Chi Hospital, The Buddhist Tzu Chi Medical Foundation, New Taipei City, Taiwan. ${ }^{3}$ Department of Ophthalmology, University of Washington, 1959 NE Pacific St, Seattle, WA, USA. ${ }^{4}$ Clinical Research Division, Fred Hutchinson Cancer Research Center, Seattle, WA, USA. ${ }^{5}$ Division of Hematopoietic Stem Cell Transplantation, National Cancer Center Hospital, Tokyo, Japan. ${ }^{6}$ Department of Bioengineering, University of Washington, Seattle, WA, USA. 'D Department of Medical Research, Division of Translational Research, Taipei Veterans General Hospital, No.201, Sec 2, Shipai Rd., Beitou District, Taipei, Taiwan. ${ }^{8}$ Department of Dentistry, School of Dentistry, National Yang-Ming Chiao Tung University, Taipei, Taiwan.
\end{abstract}

Published online: 25 January 2022

The original article can be found online at https://doi.org/10.1186/s12886021-02031-0.

*Correspondence: g38913008@gm.ym.edu.tw; ttshen@uw.edu

${ }^{3}$ Department of Ophthalmology, University of Washington, 1959 NE Pacific St, Seattle, WA, USA

${ }^{8}$ Department of Dentistry, School of Dentistry, National Yang-Ming Chiao Tung University, Taipei, Taiwan

Full list of author information is available at the end of the article

\section{Reference}

1. Sun, et al. The disposable bandage soft contact lenses therapy and anterior segment optical coherence tomography for management of ocular graft-versus-host disease. BMC Ophthalmol. 2021;21:271. https://doi.org/ 10.1186/s12886-021-02031-0.

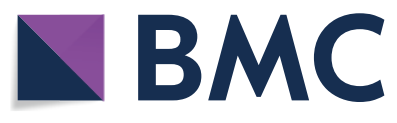

(c) The Author(s) 2021. Open Access This article is licensed under a Creative Commons Attribution 4.0 International License, which permits use, sharing, adaptation, distribution and reproduction in any medium or format, as long as you give appropriate credit to the original author(s) and the source, provide a link to the Creative Commons licence, and indicate if changes were made. The images or other third party material in this article are included in the article's Creative Commons licence, unless indicated otherwise in a credit line to the material. If material is not included in the article's Creative Commons licence and your intended use is not permitted by statutory regulation or exceeds the permitted use, you will need to obtain permission directly from the copyright holder. To view a copy of this licence, visit http://creativecommons.org/licenses/by/4.0/. The Creative Commons Public Domain Dedication waiver (http://creativeco mmons.org/publicdomain/zero/1.0/) applies to the data made available in this article, unless otherwise stated in a credit line to the data. 